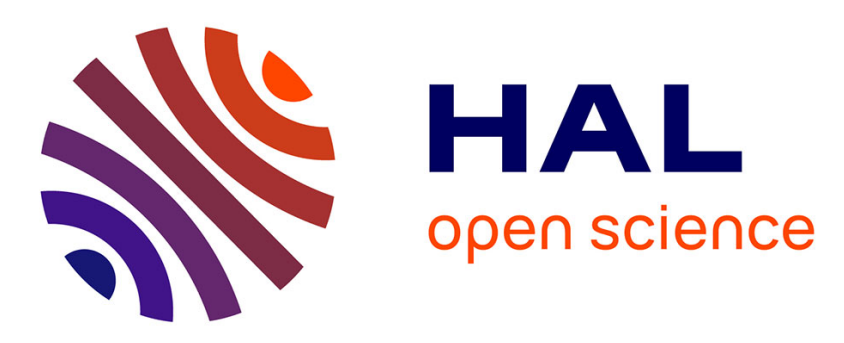

\title{
Gas-phase interactions of organotins compounds with cysteine
}

\author{
Latifa Latrous, Jean-Yves Salpin, Violette Haldys, Emmanuelle Léon, \\ Catarina Correia, Al Mokhtar Lamsabhi
}

\section{- To cite this version:}

Latifa Latrous, Jean-Yves Salpin, Violette Haldys, Emmanuelle Léon, Catarina Correia, et al.. Gasphase interactions of organotins compounds with cysteine. Journal of Mass Spectrometry, 2016, 51 (11), pp.1006-1015. 10.1002/jms.3812 . hal-01389126

\section{HAL Id: hal-01389126 \\ https://hal.science/hal-01389126}

Submitted on 3 Oct 2018

HAL is a multi-disciplinary open access archive for the deposit and dissemination of scientific research documents, whether they are published or not. The documents may come from teaching and research institutions in France or abroad, or from public or private research centers.
L'archive ouverte pluridisciplinaire HAL, est destinée au dépôt et à la diffusion de documents scientifiques de niveau recherche, publiés ou non, émanant des établissements d'enseignement et de recherche français ou étrangers, des laboratoires publics ou privés. 


\title{
Gas-phase interactions of organotin compounds with cysteine
}

\author{
Latifa Latrous $^{* 1}$, Jean-Yves Salpin*2,3, Violette Haldys ${ }^{2,3}$, Emmanuelle Léon ${ }^{2,3}$, \\ Catarina Correia ${ }^{2,3}$, Al Mokhtar Lamsabhi*4
}

${ }^{1}$ Université de Tunis El Manar, Faculté des Sciences de Tunis, Laboratoire de Chimie Analytique et Electrochimie Campus universitaire 2092, Tunis, Tunisie.

${ }^{2}$ Université d'Evry Val d'Essonne - Laboratoire Analyse et Modélisation pour la Biologie et l'Environnement Bâtiment Maupertuis -Boulevard François Mitterrand - 91025 Evry; FRANCE

${ }^{3}$ CNRS - UMR 8587

4 Departamento de Química, Ciencias, M-13. Universidad Autónoma de Madrid. Campus de Excelencia UAM-CSIC Cantoblanco, 28049-Madrid, Spain

Number of pages (including 2 Tables, 6 Figures and 2 schemes): 32

Corresponding author:

\section{Latifa Latrous}

Tel: 21697348880 Fax: 21671873948

e-mail: latifa.latrous@ipeiem.rnu.tn 


\section{Abstract}

The gas-phase interactions of cysteine with di- and tri-organotin compounds have been studied by mass spectrometry experiments and quantum calculations. Positive-ion electrospray spectra show that the interaction of di- and tri-organotins with cysteine results in the formation of $\left[(\mathrm{R})_{2} \mathrm{Sn}(\mathrm{Cys}-\mathrm{H})\right]^{+}$and $\left[(\mathrm{R})_{3} \mathrm{Sn}(\mathrm{Cys})\right]^{+}$ions, respectively. MS/MS spectra of $\left[(\mathrm{R})_{2} \mathrm{Sn}(\mathrm{Cys}-\mathrm{H})\right]^{+}$complexes are characterized by numerous fragmentation processes, notably associated with elimination of $\mathrm{NH}_{3}$ and $\left(\mathrm{C}, \mathrm{H}_{2}, \mathrm{O}_{2}\right)$. Several dissociation routes are characteristic of each given organic species.

Upon collision, both the $\left[(\mathrm{R})_{3} \mathrm{Sn}(\mathrm{Gly})\right]^{+}$and $\left[(\mathrm{R})_{3} \mathrm{Sn}(\mathrm{Cys})\right]^{+}$complexes are associated with elimination of the intact amino acid, leading to the formation of $\left[(\mathrm{R})_{3} \mathrm{Sn}\right]^{+}$cation. But for the latter complex, two additional fragmentation processes are observed, associated with the elimination of $\mathrm{NH}_{3}$ and $\mathrm{C}_{3} \mathrm{H}_{4} \mathrm{O}_{2} \mathrm{~S}$.

Calculations indicate that the interaction between organotins and cysteine is predominantly electrostatic but also exhibits a considerable covalent character, which is slightly more pronounced in tri-organotin complexes. A preferred bidentate interaction of the type $-\eta^{2}-\mathrm{S}^{-} \mathrm{NH}_{2}$, with sulfur and the amino group, is observed. As for the $\left[(\mathrm{R})_{3} \operatorname{Sn}(\mathrm{Cys})\right]^{+}$complexes, their stability is due to the combination of the hydrogen bond taking place between the amino group and the sulfur lone pair, and the interaction between the carboxylic oxygen atom and the metal. 


\section{Introduction}

The industrial, agricultural and biological applications of organotin (IV) compounds (OTCs) increased dramatically between 1960 and $1985 .{ }^{[1]}$ This resulted in their accumulation in the environment and finally in biological systems. These compounds are generally very toxic even at very low concentration. Their toxicity is correlated to the number and length of organic groups bound to tin, while the counterions do not affect organotin toxicity. ${ }^{2}$ Trialkyltin compounds with short carbon chains are the most toxic, with organotin toxicity decreasing from the methyl derivative to n-hexyl, with n-octyl being non toxic. ${ }^{[2]}$ Tetraorganotins show a delayed toxic activity in organisms. It is suggested that symptoms of poisoning could be observed only after their degradation to tri-substituted compounds. ${ }^{[3]}$

On the other hand, several organotins exhibit interesting antitumor activity in vitro. ${ }^{[4]}$ For this reason, the interaction of the organotin cations with several biologically relevant compounds such as amino acids, peptides, carbohydrates, nucleic acids and DNA has been carried out mostly in the last decade. ${ }^{[5-18]}$ The most relevant amino acids able to bind metal cations are histidine, cysteine, glutamic and aspartic acids. ${ }^{[19]}$ In aqueous solution at physiological $\mathrm{pH}$, dialkyltin (IV) and trialkyltin (IV) (with $\mathrm{R}=\mathrm{CH}_{3}$, $\mathrm{C}_{2} \mathrm{H}_{5}, \mathrm{C}_{4} \mathrm{H}_{9}$ ) compounds form tetrahedral or trigonal bipyramidal complexes, which involves covalent Sn-S bonds and further coordination by nitrogen donors, from cysteine and histidine side chain, respectively. ${ }^{[11,12]}$ Cysteine is the only naturally occurring sulfur-containing amino acid. It is synthesized in living organism from the essential amino acid methionine under normal physiologic conditions. The total concentrations for blood plasma models show that among the amino acids cysteine is present at the highest concentration, with a value $\geq 100 \mu \mathrm{L} \mathrm{mol}^{-1} .{ }^{[20]}$ Cysteine and its derivatives have attracted special attention because of their involvement in many 
important biological processes and are known to be active sites both in the catalytic function of the enzymes cysteine proteases and in several peptides and proteins. ${ }^{[21]}$ It is indeed recognized that cysteine can coordinate metal cations through sulfur sites in several proteins and metalloenzymes. ${ }^{[21-24]}$.

Interactions between several metal cations and cysteine have been studied. Nemirovskiy et al. examined the interaction between cysteine-containing peptides and iron(II) using fast atom bombardment and tandem mass spectrometry. ${ }^{[25,26]}$ They showed that Fe-S interactions are preserved in the gas phase and are the basis of highly specific fragmentations. The $\mathrm{Co}(\mathrm{II})$ complexation by cysteine has also been investigated. ${ }^{[27]}$ Authors used electrospray ionization (ESI) coupled to mass spectrometry (MS) to characterize the resulting complexes and confirmed the high affinity of cobalt(II) towards the sulfur atom. Energetic studies involving interactions of cysteine with alkali metal cations, $\mathrm{Be}^{2+}, \mathrm{Ca}^{2+}$ and $\mathrm{Mg}^{2+}$ have also been published. ${ }^{[28-33]}$ Concerning the interactions between organotins and cysteine, various studies using potentiometry ${ }^{[13,14]}$ and Mössbauer spectroscopic methods have been reported. ${ }^{[15-17]}$ To the best of our knowledge, the interactions taking place between OTCs and cysteine has not been explored so far by mass spectrometry, and this is the purpose of the present study. Gas-phase studies can indeed provide new information about these interactions. In this paper, we report our systematic investigations on the interactions of cysteine with OTCs. Gas-phase organotin/cysteine complexes were produced by electrospray ionization (ESI), and their unimolecular reactivity upon collision has been extensively studied. In order to rationalize our experimental findings, we also carried out computations using the M11L hybrid density functional.

\section{Experimental}




\section{Mass spectrometry}

Electrospray-ionization mass spectra were recorded on a QSTAR PULSAR XL (Applied Biosystems/MDS Sciex) hybrid instrument (QqTOF) fitted with a nanoelectrospray source. Several $\mu \mathrm{L}$ of cysteine/OTC mixtures $\left(510^{-4} \mathrm{M} / 10^{-4} \mathrm{M}\right.$ in $50 / 50$ methanol/milli-Q water were nanosprayed $\left(20-50 \mathrm{~nL} \mathrm{~min}^{-1}\right)$ using borosilicate emitters (Proxeon). Samples were ionized using a $900 \mathrm{~V}$ nanospray needle voltage and the lowest possible nebulizing gas pressure (tens of millibars). The declustering potential DP (also referred to as "cone voltage" in other devices), defined as the difference in potentials between the orifice plate and the skimmer (grounded), was varied from 0 to $120 \mathrm{~V}$ for optimization purpose and was finally set to $50 \mathrm{~V}$ to perform all the experiments. To record MS/MS spectra, ions of interest were mass-selected by using quadrupole Q1, and allowed to collide with nitrogen gas at various collision energies ranging from 8 to $25 \mathrm{eV}$ in the laboratory frame (the collision energy is given by the difference of potentials between Q0 and Q2) with the resulting fragment ions separated by the time-of-flight (TOF) analyzer after orthogonal injection. The CAD parameter, which roughly controls the amount of $\mathrm{N}_{2}$ introduced into $\mathrm{Q} 2$, was set to its minimum value (1) in order to limit multiple ion-molecule collisions. This resulted in pressure values of $1-210^{-5}$ Torr as measured by the ion gauge located at vicinity but outside the collision cell, but it has been reported ${ }^{[34-36]}$ that the pressure inside the collision cell is in fact in the order of 10 mTorr. Consequently at this pressure, even with the minimum amount of $\mathrm{N}_{2}$ inside the collision cell, and as we already discussed in previous papers, ${ }^{[35,36]}$ we are certainly under a multiple collision regime.

Unless otherwise noted, mass to charge ratios $(\mathrm{m} / \mathrm{z})$ mentioned throughout this paper refer to as peaks which include the most abundant tin isotope $\left({ }^{120} \mathrm{Sn}\right)$. Cysteine, methanol (HPLC grade), triphenyltin chloride (TPhTCl), tributyltin chloride (TBTCl), 
dibutyltin dichloride $\left(\mathrm{DBTCl}_{2}\right.$; purity $\left.\geq 96 \%\right)$, diphenyltin dichloride $\left(\mathrm{DPhTCl}_{2}\right.$; purity $\geq 93 \%$ ) were purchased from Sigma-Aldrich (Saint-Quentin Fallavier, France), while dimethyltin dichloride $\left(\mathrm{DMTCl}_{2}\right)$ and trimethyltin chloride (TMTCl) were purchased from Riedel de Haen (Seelze, Germany).

\section{Computational details}

Density functional theory (DFT) calculations were carried out using the M11-L pure functional ${ }^{[37]}$, as implemented in the Gaussian 09 suite of programs. ${ }^{[38]}$ This functional, proposed recently by Truhlar's group has shown reliable results for heavy atoms. $^{[37,39-43]}$ The Def2-SVP ${ }^{[44]}$ basis set and effective core potential was used to describe the tin atom, while for the remaining atoms the $6-31+G(d, p)$ basis set was chosen. The choice of this basis set is based on the recent work done by Piotr Matczak who showed that the use of this basis set resulted in small errors. ${ }^{[45]}$ Harmonic vibrational frequencies were computed at the same level in order to estimate the corresponding zero-point vibrational energy (ZPVE) corrections and to classify the stationary points of the potential energy surfaces (PES) either as local minima or transition states (TS). Intrinsic reaction coordinate (IRC) calculations were carried out to ascertain the connection between TS and local minima. In order to ensure the reliability of our relative energies when analyzing the topology of the corresponding potential energy surface (PES), the final energy of each of the stationary points was refined by single-point calculations at $\operatorname{CCSD}(\mathrm{T})$ level of theory combined with the same basis set.

To get more information about the electronic (charge transfer; covalency) and electrostatic factors that contribute to the binding of tin with cysteine, the ETS-NOCV energy decomposition scheme has been used to obtain the binding energy of the most 
stable complexes. This scheme, which originates from a combination of the extended transition state $(\mathrm{ETS})^{[46]}$ energy decomposition approach with the natural orbitals for chemical valence $(\mathrm{NOCV})$ analysis ${ }^{[47,48]}$, presents the binding energy as the sum of three energy components: i) the electrostatic interaction energy, $\Delta \mathrm{E}_{\text {elstat }}$, which corresponds to the classical electrostatic interaction between the fragments involved ii) the Pauli repulsion energy, $\Delta \mathrm{E}_{\text {Pauli }}$, which accounts for the repulsive Pauli interaction between occupied orbitals on the fragments in the complex, and iii) the orbital interaction energy, $\Delta \mathrm{E}_{\text {orb}}$, which represents the interactions between the occupied molecular orbitals of one fragment with the unoccupied molecular orbitals of the other fragments. To obtain this decomposition, the Amsterdam Density functional (ADF) suite of programs ${ }^{[49]}$ has been used by applying the ETS-NOCV procedure at the M11L/TZ2P level of theory on the optimized structures.

The bonding characteristics were also investigated by means of the quantum theory of atoms in molecules (QTAIM) ${ }^{[50,51]}$ in particular through the analysis of the molecular graphs and of the energy density,

$$
h(\vec{r})=v(\vec{r})+g(\vec{r})
$$

where $v(\vec{r})$ and $g(\vec{r})$ are the local densities of the kinetic energies, respectively. The regions in which this magnitude is negative or positive correspond to areas in which the electron density is built up or depleted, respectively, so that the former can be associated with covalent interactions, whereas the latter are typically associated with closed-shell interactions, as in ionic bonds or hydrogen bonds. The molecular graphs are defined by the ensemble of the bond critical points and the bond paths. The corresponding density energy plots have been obtained by means of the AIMAll series of programs. ${ }^{[52]}$ 
A complementary viewpoint, sometimes crucial to understand bonding can be obtained through the use of the NBO (Natural Bond Orbital) approach, ${ }^{[53]}$ which describes the bonding in terms of localized hybrids obtained as local block eigenvectors of the one-particle density matrix. A second order perturbation treatment also allows quantifying the interaction energies between occupied and empty orbitals reflected in a charge transfer from the former to the latter. These kinds of interactions are typically found in $\mathrm{XH} \cdots \mathrm{Y}$ hydrogen bonds, which are characterized by a charge transfer from the lone-pairs of the $\mathrm{HB}$ acceptor $\mathrm{Y}$, into the antibonding $\sigma_{\mathrm{XH}}{ }^{*}$ orbital of the $\mathrm{HB}$ donor, $\mathrm{XH}$.

\section{Result and Discussion}

\section{Mass spectrometry}

\section{Cys/di-organotins}

Figure 1a presents the electrospray ionization mass spectrum obtained at $\mathrm{DP}=$ $50 \mathrm{~V}$ for a 1:5 $\mathrm{DPhTCl} /$ cysteine mixture. Interaction between cysteine and DPhTCl gives rise to a singly charged complexes of general formula $\left[(\mathrm{Ph})_{2} \mathrm{Sn}(\mathrm{Cys}-\mathrm{H})\right]^{+}$, detected at $\mathrm{m} / \mathrm{z} 393.93$ and associated with formal deprotonation of cysteine. Consistently, studies performed in aqueous solution have shown that interaction of diorganotin with L-cysteine is accompanied by deprotonation of the ligand. ${ }^{[54]}$ Tin-containing ions can be easily identified because of the specific isotopic distribution of this metal, resulting in characteristic isotopic profiles. Consequently, most of the ions detected in the 300-400 mass range include one tin atom and correspond (vide infra) to fragments arising from the initial complex. Note that the isotopic profiles also confirm the lack of any chloride atom. The three species detected at $\mathrm{m} / \mathrm{z} 376.93$ and 347.92 and 315.92 result from the loss of $\mathrm{NH}_{3},\left(\mathrm{C}, \mathrm{H}_{2}, \mathrm{O}_{2}\right)$ and benzene, respectively. The protonated form of cysteine 
[Cys] $\mathrm{H}^{+}$is detected at $m / z$ 122.02, and further fragments within the interface according to losses of $\mathrm{NH}_{3}$ and $\left(\mathrm{C}, \mathrm{H}_{2}, \mathrm{O}_{2}\right)$ to generate $\mathrm{m} / z, 105.00$ and 76.02 ions. Similar spectra were obtained with both dimethyltin dichloride and dibutyltin dichloride. Note that the $m / z \quad 354.03$ ion presently observed is certainly a trace of the $\left[(\mathrm{nBu})_{2} \mathrm{Sn}(\mathrm{Cys}-\mathrm{H})\right]^{+}$ complex from another series of experiments.

Globally, the electrospray spectra obtained with di-organotins are markedly simple. Only mononuclear complexes are observed. We did not detect any binuclear complexes complexes of the type $\left[(\mathrm{R})_{2} \mathrm{Sn}(\mathrm{Cys})_{2} \mathrm{H}\right]^{-}$and $\left[(\mathrm{R})_{2} \mathrm{Sn}(\mathrm{Cys})_{2}\right]^{2-}$ known to be formed in water. ${ }^{[54]}$ Finally, we do not detect any polynuclear complexes, the isotopic distribution of tin-containing ions being systematically consistent with the presence of a single metallic center.

\section{Cys/tri-organotins}

To examine the interaction between cysteine and tri-organotin compounds, various mixtures in methanol-water were tested (OTC/Cys ratios were 1/1, 1/5, 1/7 and 1/10). No complexes resulting from the interaction of the two partners were obtained with TBTCl and TPhTCl. In the case of trimethyltin chloride, the nanoelectrospray spectrum (not shown) of a mixture of cysteine/trimethyltin chloride $\left[10^{-3}\right] /\left[10^{-4}\right] \mathrm{M}$ in methanol water $(50 / 50 \mathrm{v} / \mathrm{v})$ resulted in the formation of the $\left[\left(\mathrm{CH}_{3}\right)_{3} \mathrm{SnCys}\right]^{+}$ion $(\mathrm{m} / \mathrm{z}$ 286.00). Interaction between cysteine and organotins in the gas phase is therefore more facilitated if tin is less substituted. In addition to protonated cysteine, the mass spectrum is dominated by an intense peak associated with the $\left[\left(\mathrm{CH}_{3}\right)_{3} \mathrm{Sn}\right]^{+}$entity.

\section{MS/MS experiments}


Tandem mass spectrometry experiments were performed in order to gain some insights into both the mechanism of dissociation and structure of the $\left[(\mathrm{R})_{2} \mathrm{Sn}(\mathrm{Cys}-\mathrm{H})\right]^{+}$ and $\left[(\mathrm{R})_{3} \mathrm{SnCys}\right]^{+}$ions. Unimolecular reactivity of $\left[(\mathrm{R})_{3} \mathrm{SnCys}\right]^{+}$is different from diorganotin complexes. MS/MS spectra of $\left[\left(\mathrm{CH}_{3}\right)_{3} \mathrm{SnCys}\right]^{+}$ions is illustrated by Figure 2a. Elimination of intact cysteine leading to the formation of the $\left[\left(\mathrm{CH}_{3}\right)_{3} \mathrm{Sn}\right]^{+}$ carbocation $(\mathrm{m} / \mathrm{z} 165)$ is observed. Unlike what was observed with glycine ${ }^{[55]}$, several additional fragmentation processes occur (Scheme 1). Two other fragment ions are indeed detected, associated with the elimination of $\mathrm{NH}_{3}\left(\mathrm{~m} / z\right.$ 269) and $\mathrm{C}_{3} \mathrm{H}_{4} \mathrm{O}_{2} \mathrm{~S}(\mathrm{~m} / z$ 182). The formation of $\left[\left(\mathrm{CH}_{3}\right)_{3} \mathrm{Sn}\right]^{+}$can be also derived from the loss of $\mathrm{NH}_{3}$ from the fragment ion $\left[\left(\mathrm{CH}_{3}\right)_{3} \mathrm{Sn} \mathrm{NH}\right]^{+}(\mathrm{m} / \mathrm{z}, 182)$, and from elimination of $\mathrm{C}_{3} \mathrm{H}_{4} \mathrm{O}_{2} \mathrm{~S}$ from the fragment ion $\left[\left(\mathrm{CH}_{3}\right)_{3} \mathrm{SnCys},-\mathrm{NH}_{3}\right]^{+}(\mathrm{m} / z$ 269). These results suggest the formation of an intermediate in which $\mathrm{NH}_{3}$ and $\mathrm{C}_{3} \mathrm{H}_{4} \mathrm{O}_{2} \mathrm{~S}$ could interact with the metallic center. The fragmentation patterns observed with cysteine and glycine are therefore different, elimination of the amino acid being the unique process observed with the latter. ${ }^{[55]}$

Loss of intact cysteine from the complexes was reported by Armentrout et al. in their study about the interaction of alkali metal cations $\left(\mathrm{M}^{+}=\mathrm{Li}^{+}, \mathrm{Na}^{+}, \mathrm{K}^{+}\right.$and $\left.\mathrm{Rb}^{+}\right)$ with cysteine. ${ }^{[28,31]}$ In addition, they observed elimination of ammonia in the collision induced dissociation spectrum of $\mathrm{Li}^{+}(\mathrm{Cys})$. They demonstrated that this process corresponds to the transfer of hydrogen from the carboxylic acid group to the amino group, followed by backside attack of the thiol group at the $\alpha$ carbon to induce cleavage of the C-N bond. The $\mathrm{C}_{3} \mathrm{H}_{4} \mathrm{O}_{2} \mathrm{~S}$ product formed in this reaction is likely to be thiiranecarboxylic acid (Tica). ${ }^{[31]}$

MS/MS spectra of the complexes obtained with the di-organotin compounds are illustrated by Figure $2 \mathrm{~b}$ for $\mathrm{DMTCl}_{2}$. Upon collision, the three $\left[(\mathrm{R})_{2} \mathrm{Sn}(\mathrm{Cys}-\mathrm{H})\right]^{+}$ complexes share several fragmentation processes as described by Scheme 2. Two 
fragment ions are indeed systematically observed, associated with elimination of $\mathrm{NH}_{3}$ and $(\mathrm{m} / z, 252.93)$ and $\left(\mathrm{C}, \mathrm{H}_{2}, \mathrm{O}_{2}\right)(\mathrm{m} / z$ 223.95). All the dissociation processes mentioned so far are observed for the three di-organotin compounds studied (See supporting information, Figure S1). However, as mentioned in scheme 2, several dissociation routes are characteristic of a given organic substituent. The $\left[(\mathrm{R})_{2} \mathrm{Sn}(\mathrm{Cys}-\mathrm{H}) ;-\mathrm{NH}_{3}\right]^{+}$ion gives characteristic dissociations for $\mathrm{R}=\mathrm{CH}_{3}$ and $\mathrm{R}=\mathrm{Ph}$. These fragmentations correspond to the elimination of $\mathrm{CO}\left(\mathrm{R}=\mathrm{CH}_{3}\right)$ and $\mathrm{CO}_{2}\left(\mathrm{R}=\mathrm{CH}_{3}\right.$ and $\left.\mathrm{R}=\mathrm{Ph}\right)$. In addition, elimination of intact cysteine $(121 \mathrm{u})$ from the $\left[(\mathrm{R})_{2} \mathrm{Sn}(\mathrm{Cys}-\mathrm{H})\right]^{+}$complex is specifically observed for $\mathrm{R}=\mathrm{n}-\mathrm{Bu}$, and gives rise to $[(\mathrm{R}) \mathrm{Sn}(\mathrm{R}-\mathrm{H})]^{+}$ion $(m / z, 233$, see Figure S1). Again, in the particular case of the $\mathrm{DPhTCl}_{2}$, loss of a (RH) neutral moiety is observed from $\left[(\mathrm{Ph})_{2} \mathrm{Sn}(\mathrm{Cys}-\mathrm{H})\right]^{+}$ion, leading to $\left[(\mathrm{Ph}) \mathrm{Sn}(\mathrm{Cys})-\mathrm{H}_{2}\right]^{+}$at $m / z$ 316. The fragmentation patterns observed with cysteine and glycine again exhibit some differences. The most noticeable difference is the complete lack of dehydration in the case of cysteine.

The unimolecular reactivity of these complexes upon collision appears somehow similar to that observed with other metal cations such as $\mathrm{Co}(\mathrm{II})$ and $\mathrm{Li}(\mathrm{I})$. For example, cysteine deamination has also been observed experimentally for $\left[\mathrm{Co}(\mathrm{Cys})_{2}-\mathrm{H}\right]^{+[11]}$. The loss of amino acid and elimination of ammonia are observed in the collision-induced dissociation of $\mathrm{Li}^{+}(\mathrm{Cys})^{[28,31]}$. For this particular system, the lowest energy pathway located for $\mathrm{NH}_{3}$ loss involves a hydrogen transfer from the carboxylic acid group to the amino group followed by backside attack of the thio group at the $\alpha$ carbon, promoting the cleavage of the $\mathrm{C}-\mathrm{N}$ bond. Elimination of 46 mass units is also characteristic of $[\mathrm{Co}(\mathrm{Cys})-\mathrm{H}]^{+} .{ }^{[11]}$ The elemental composition associated with the latter is the loss of $\left(\mathrm{C}, \mathrm{H}_{2}, \mathrm{O}_{2}\right)$ fragment which may correspond either to formic acid $(\mathrm{HCOOH})$, dihydroxycarbene $\left(\mathrm{C}(\mathrm{OH})_{2}\right)$, or combined elimination of $\mathrm{H}_{2}+\mathrm{CO}_{2}$ or $\mathrm{H}_{2} \mathrm{O}+\mathrm{CO}$. On 
the other hand, direct elimination of carbon dioxide from the initial $\left[(\mathrm{R})_{2} \mathrm{Sn}(\mathrm{Cys}-\mathrm{H})\right]^{+}$ and $\left[(\mathrm{R})_{3} \mathrm{SnCys}\right]^{+}$complexes is not observed.

\section{Computational study}

Coordination of trimethyl and dimethyltin with Cysteine.

To understand the reactivity of the trimethyl tin (TMT) and the dimethyltin tin (DMT) species towards cysteine, it is mandatory to explore the type of interaction that could take place between the metal and the amino acid. For this reason, we have considered all the possible positions that the metal could take for complex formation given the most probable binding sites (heteroatoms). The optimization of the resulting structures was carried out at the $\mathrm{M} 11 \mathrm{~L} / 6-31+\mathrm{G}^{* *}$ level of theory. Given the high number of conformers that cysteine moiety could adopt, we chose the eleven most stable ones (see Figure S2 in the Supporting Information) as the most probable structures that could interact with TMT or DMT. The resulting structures for $\left[\left(\mathrm{CH}_{3}\right)_{2} \mathrm{Sn}(\mathrm{Cys}-\mathrm{H})\right]^{+}$and $\left[\left(\mathrm{CH}_{3}\right)_{3} \mathrm{Sn}(\mathrm{Cys})\right]^{+}$complexes are reported in Figures 3 and 4, respectively. The various structures are labeled according to the following convention: the interacting centers (i.e. $\mathrm{O}, \mathrm{S}, \mathrm{NH} 2 .$. etc) are specified after the name of organotin, augmented by a number to differentiate the different conformers of a given binding scheme. A letter " $\mathrm{Z}$ " is added when zwitterionic forms of cysteine are involved in the coordination process. Note also that the number of optimized complexes does not match the number of forms initially considered, the optimization step, in some cases, converging towards the same structure. For the $\left[\left(\mathrm{CH}_{3}\right)_{2} \mathrm{Sn}(\mathrm{Cys}-\mathrm{H})\right]^{+}$complex, the most stable structure is DMT- $\eta^{\mathbf{2}} \mathbf{- S}-\mathbf{N H 2}$ which involves a bidentate interaction of the metal with the sulfur atom and the amino group (see Figure 3). This confirms that the most acidic group of cysteine is likely the thiol group as it has been shown recently by Muetterties et al. in their study on 
homocysteine. ${ }^{[56]}$ The second most stable complex, DMT- $\boldsymbol{\eta}^{\mathbf{2}} \mathbf{- Z - O}, \mathbf{S}-\mathbf{2}$, also involves the most acidic site of cysteine, and is located $31 \mathrm{~kJ} / \mathrm{mol}$ above the global minimum. In this case, the carboxylic group has transferred its proton to the amino group giving rise to an interaction with a S-deprotonated zwitterionic form of cysteine. The N-deprotonated form, DMT- $\boldsymbol{\eta}^{\mathbf{2}} \mathbf{- S H}-\mathbf{N H}$, lies higher in energy (around $102 \mathrm{~kJ} / \mathrm{mol}$ above the global minimum). Unlike what was found in the $\left[\left(\mathrm{CH}_{3}\right)_{2} \mathrm{Sn}(\mathrm{Gly}-\mathrm{H})\right]^{+}$complexes, ${ }^{[55]}$ the interaction of the metal with the carboxylic group appears clearly disfavored against the binding with the other reactive sites ( $\mathrm{N}$ and $\mathrm{S}$ ). This behavior could be associated with the particularly strong interaction taking place between the metal and the sulfur, as compared to the binding involving either nitrogen or oxygen. In fact, its deprotonation added to the great polarizability of sulfur enhances the interaction with tin, making the bond formed as strong as a covalent bond. The ETS-NOCV energy decomposition scheme shows a strong interaction between DMT and Cys-H species in the two most stable complexes (See Supporting Information for detailed data). For DMT- $\boldsymbol{\eta}^{\mathbf{2}} \mathbf{- S , N H 2}$ and DMT- $\boldsymbol{\eta}^{\mathbf{2}} \mathbf{- Z}-\mathbf{O}, \mathbf{S}-\mathbf{2}$ complexes, the interaction energy $\Delta \mathrm{E}_{\text {Int }}$ was estimated about 1670 and $-1733 \mathrm{~kJ} / \mathrm{mol}$, respectively. The electrostatic interaction $\left(\Delta \mathrm{E}_{\text {elstat }}\right)$ is the most important in both structures with a participation of $65 \%$ in the attractive component of the interaction energy $\left(-1660 \mathrm{~kJ} / \mathrm{mol}\right.$ for DMT- $\boldsymbol{\eta}^{2} \mathbf{- S , N H 2}$ and $-1676 \mathrm{~kJ} / \mathrm{mol}$ for DMT$\boldsymbol{\eta}^{2}$-Z-O,S-2). The other attractive component $\left(\Delta \mathrm{E}_{\mathrm{orb}}\right)$, which involves the charge transfer between the frontier orbitals and characterizes the covalent character of the interaction, contributes to $35 \%$ of the attractive part of the interaction energy $(-904 \mathrm{~kJ} / \mathrm{mol}$ for DMT- $\boldsymbol{\eta}^{2}-\mathbf{S}, \mathbf{N H 2}$ and $-911 \mathrm{~kJ} / \mathrm{mol}$ for DMT- $\left.\boldsymbol{\eta}^{2}-\mathbf{Z}-\mathbf{O}, \mathbf{S}-2\right)$. If we closely look at the coordination of sulfur with the metal in these complexes, Wiberg bond index (Table 1) shows a value close to unity which indicates a strong S-Sn bond (see Table 1). The AIM analysis reports a considerable electron density $(0.085$ a.u $)$ at the bond critical point 
(BCP) associated with this binding, with a negative value of the energy density (see Figure S3 in the Supporting Information). Consequently, in these two complexes, the interaction between $\mathrm{S}$ and $\mathrm{Sn}$ is predominantly electrostatic with a considerable covalent character. When involving nitrogen and oxygen, the interaction is still predominantly electrostatic with trends similar to those shown for $\left[\left(\mathrm{CH}_{3}\right)_{2} \mathrm{Sn}(\mathrm{Gly}-\mathrm{H})\right]^{+}$complexes. ${ }^{[55]}$ Complexes obtained with tri-organotins have also been studied theoretically. As mentioned in the experimental section, tri-organotins interacts with cysteine to generate $\left[\left(\mathrm{R}_{3}\right) \operatorname{Sn}(\mathrm{Cys})\right]^{+}$complexes in the gas phase. Figure 4 presents the different forms optimized for the $\left[\left(\mathrm{CH}_{3}\right)_{3} \mathrm{SnCys}\right]^{+}$complex. It is worth noting that only monodentate interaction was found. The global minimum obtained corresponds to TMT- $\boldsymbol{\eta}^{\mathbf{1}}$-NH2-1 and implies an interaction between the metal and the amino group of a neutral cysteine. The second most stable form, namely TMT- $\boldsymbol{\eta}^{\mathbf{1}} \mathbf{- Z - O} \mathbf{- 1}$, is nearly degenerate as it lies only $2 \mathrm{~kJ} / \mathrm{mol}$ (at the $\operatorname{CCSD}(\mathrm{T}) / 6-31+\mathrm{G}^{* *} / / \mathrm{M} 11 \mathrm{~L} / 6-31+\mathrm{G}^{* *}$ level of theory) above the global minimum. This form is characterized by an interaction with the carboxylate group of a zwitterionic cysteine. The energy gap between the two most stable forms is therefore strongly reduced for TMT complexes as compared to DMT complexes. The complex involving the sulfur atom (TMT- $\boldsymbol{\eta}^{\mathbf{1}} \mathbf{- Z - S - 1}$ structure in Figure 4.) is about 18 $\mathrm{kJ} / \mathrm{mol}$ above the global minimum. It is also worth mentioning that among the various forms optimized for the TMT-cysteine complexes (Figure 4), many structures are characterized by the presence of one or two strong intramolecular hydrogen bonds (HB). For example, for the most stable form TMT- $\eta^{\mathbf{1}} \mathbf{- N H 2 - 1}$, a hydrogen bond is established between the amino group (HB donor) and the sulfur lone pair (HB acceptor). Two strong hydrogen bonds stabilize the near-isoenergetic complex TMT$\eta^{1}-\mathbf{Z}-\mathbf{O}-1$, one involving the carboxylic oxygen atom and the hydrogen amine, and the second HB taking place between the hydrogen of the thiol group and the remaining 
carboxylic group oxygen atom. In the complexes involving a zwitterionic form of cysteine, the hydrogen bonds associated with the ammonium group are the strongest.

Analyzing the natural charge of the metal, we can see that in both complexes the metal presents a small charge variation (between 1.9 to $2.0 e$ ) which basically depends on the reactive center involved. However, the natural charge transferred to the cysteine moiety in TMT $(0.205$ to $0.38 e)$ or to the deprotonated cysteine in DMT $(>1 e)$ is sensibly different showing that the bindings in the latter are more enhanced than in the former. From the ETS-NOCV energy decomposition scheme, one can conclude that for TMT complexes, the interaction is predominantly electrostatic, regardless the interaction site. It is worth noting that the interaction energies $\Delta \mathrm{E}_{\text {Int }}$ for TMT- $\eta^{\mathbf{1}} \mathbf{- Z - O - 1}$ and TMT- $\boldsymbol{\eta}^{\mathbf{1}}$ NH2-1 considerably smaller than those computed for the DMT complexes. The electrostatic energy term $\Delta \mathrm{E}_{\text {elstat }}$ is $-345 \mathrm{~kJ} / \mathrm{mol}$ for the former and $-291 \mathrm{~kJ} / \mathrm{mol}$ for the latter, whereas the orbital interaction energy term $\Delta \mathrm{E}_{\text {orb }}$ for each complex is about -207 and $-196 \mathrm{~kJ} / \mathrm{mol}$, respectively. The ETS-NOCV energy decomposition scheme shows a slightly more important covalent character in the interaction energy between TMT and cysteine as compared to DMT. Indeed, in the first three most stable TMT complexes, the $\Delta \mathrm{E}_{\text {Orb }}$ component accounts for $\sim 41 \%$ of the whole attraction energy, hence slightly higher than that observed with DMT complexes. Note that the covalent character of the linkage between tin and cysteine heteroatoms can also be deduced from the Wiberg bond index values in the most relevant complexes (see Table 2).

Unimolecular Fragmentation of $\left[\left(\mathrm{CH}_{3}\right)_{2} \mathrm{Sn}(\mathrm{Cys}-\mathrm{H})\right]^{+}$and $\left[\left(\mathrm{CH}_{3}\right)_{3} \mathrm{Sn}(\mathrm{Cys})\right]^{+}$ complexes.

DMT and TMT organotins exhibit different chemical and physical properties which result in different binding schemes, as illustrated by the DFT study. It is therefore not surprising that the dissociation upon collision observed for the $\left[\left(\mathrm{CH}_{3}\right)_{2} \mathrm{Sn}(\mathrm{Cys}-\mathrm{H})\right]^{+}$ 
and $\left[\left(\mathrm{CH}_{3}\right)_{3} \mathrm{Sn}(\mathrm{Cys})\right]^{+}$ions is different. To get further insight about this unimolecular reactivity, we have explored the topology of the potential energy surfaces associated with the fragmentation of both $\left[\left(\mathrm{CH}_{3}\right)_{2} \mathrm{Sn}(\mathrm{Cys}-\mathrm{H})\right]^{+}$and $\left[\left(\mathrm{CH}_{3}\right)_{3} \mathrm{Sn}(\mathrm{Cys})\right]^{+}$ions, which led us to propose mechanisms accounting for the formation of the most intense peaks, namely $\mathrm{m} / z 253$ and 224 fragments ions for the former, and $\mathrm{m} / \mathrm{z} 269$ and 182 ions for the latter. For the DMT/cysteine complex, these dissociations involve the loss of $\mathrm{NH}_{3}$ and $\left(\mathrm{C}, \mathrm{H}_{2}, \mathrm{O}_{2}\right)$ neutrals, respectively, while for the TMT/cysteine system, the peaks are associated with the loss of $\mathrm{NH}_{3}$ and $\mathrm{C}_{3} \mathrm{H}_{4} \mathrm{O}_{2} \mathrm{~S}$ entities.

In order to explore the potential energy surfaces associated with the most relevant dissociation processes of the $\left[\left(\mathrm{CH}_{3}\right)_{2} \mathrm{Sn}(\mathrm{Cys}-\mathrm{H})\right]^{+}$complex, we took the two

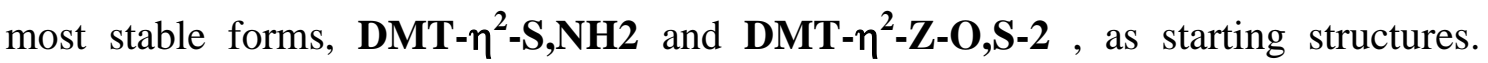
Given the energy gap between these two forms, assuming a Maxwell-Boltzmann population distribution would result in a negligible proportion of the latter. However, interconversion between the different structures is likely to occur prior to dissociation. In a recent series of paper dedicated to the structure and unimolecular reactivity of protonated uracil, ${ }^{[57-60]}$ we showed that the protonated form actually generated in the gas phase by electrospray was not reactive, and its interconversion into other protomers was mandatory to account for the fragmentation observed experimentally. The results presented in Figure 5 confirm this statement, since interconversion between DMT- $\eta^{2}$ S,NH2 and DMT- $\eta^{2}-\mathbf{Z}-\mathbf{O}, \mathbf{S}-2$ requires less energy than the formation of the fragment ions. Consequently, it is reasonable to expect statistical sampling among the various forms prior to dissociation. Note also that all our attempts to find a simple mechanism to produce ammonia directly from the DMT- $\eta^{2}-\mathbf{S}, \mathbf{N H 2}$ complex (through a proton transfer from the nearest methylene group) failed, leading either to huge activation energies or to transition state structures connecting weird minima (according to IRC 
calculations). The best mechanism that could be proposed is formation of the $\mathrm{NH}_{3}$ fragment by a PES involving DMT- $\eta^{2}-\mathbf{Z}-\mathbf{O}, \mathbf{S - 2}$ complex as intermediate (see Figure 5). Ultimately, $\mathrm{NH}_{3}$ could be detached easily from DMT- $\eta^{2}-\mathbf{Z}-\mathbf{O}, \mathbf{S - 2}$ structure since no intrinsic transformations are needed. From DMT- $\eta^{2}-\mathbf{Z}-\mathbf{O}, \mathbf{S - 2}$, one has to overcome an energy barrier of about $117 \mathrm{~kJ} / \mathrm{mol}$ through the transition state DMT-TS3, to form the minimum

DMT-min3, which needs about $42 \mathrm{~kJ} / \mathrm{mol}$ to produce the $\mathrm{NH}_{3}$ fragment.

The second most abundant peak observed experimentally (Figure 2b), corresponds to the elimination of a $\left(\mathrm{C}_{2} \mathrm{H}_{2}, \mathrm{O}_{2}\right)$ moiety $(\mathrm{m} / \mathrm{z} 224)$. This fragmentation is commonly observed for both cationized and protonated amino acids. Based on previous combined experimental and theoretical studies on protonated ${ }^{[61]}$ and copper-cationized ${ }^{[62]}$ glycine, one may reasonably assume that this could be associated with combined elimination of $\mathrm{CO}$ and $\mathrm{H}_{2} \mathrm{O}$. However, to reach such losses, the structure of the most stable complexes has to undergo many intrinsic transformations to reach the desired species. This led us to look for a neutral fragment with the same molecular mass that could subsequently evolve towards these molecules under the experimental conditions. In this respect, elimination of HOCOH from DMT- $\eta^{2}-\mathbf{S , N H 2}$ appears as a possible mechanism (Figure 5). In a first step, a hydrogen transfer from $\mathrm{NH} 2$ to the carbonyl group can lead to the DMT-min12 intermediate, which exhibits a $\mathrm{HOCOH}$ moiety. This step requires an activation energy of $242 \mathrm{~kJ} / \mathrm{mol}$. The second step proposed is the dissociation of this group, associated with an energy barrier of about $49 \mathrm{~kJ} / \mathrm{mol}$, leading to DMT-min4 and ultimately to the elimination of dihydroxycarbene $(\mathrm{HOCOH})$. If we want to go further and reach the formation of $\mathrm{H}_{2} \mathrm{O}+\mathrm{CO}$, there are two possibilities which are presented in the Supporting Information (Figure S5): an intrinsic hydrogen transfer in DMT-min4 complex whose barrier is about $145 \mathrm{~kJ} / \mathrm{mol}$, or a similar hydrogen transfer occurring 
within the isolated HOCOH (DMT-TS5), leading to water and carbon monoxide. In this case, the barrier is about $136 \mathrm{~kJ} / \mathrm{mol}$ at the $\operatorname{CCSD}(\mathrm{T}) / 6-31+\mathrm{G}^{* *} / / \mathrm{M} 11 \mathrm{~L} / 6-31+\mathrm{G}^{* *}$ level of theory.

To investigate the dissociation of the TMT-cysteine system, a similar procedure has been used. Assuming a Maxwell-Boltzmann population distribution among the various forms gives the following repartition: $50 \%, 46 \%$ and $4 \%$ of TMT$\eta^{1}$-NH2-1, TMT- $\eta^{1}-Z-O-1$ and TMT- $\eta^{1}-Z-S-1$, respectively. Assuming the possible interconversion between various forms and notably these three structures prior to dissociation, all the possible pathways that could lead to the formation of $\mathrm{NH}_{3}$ and $\mathrm{C}_{3} \mathrm{H}_{4} \mathrm{O}_{2} \mathrm{~S}$ from these three forms have been explored. This study, carried out at the same level of theory as for DMT complexes, is summarized in Figure 6. Considering first the elimination of $\mathrm{NH}_{3}$, two possible pathways both originating from a complexed zwitterionic form of cysteine could be proposed. The two mechanisms need to overcome a barrier for C-N bond cleavage. If we take the TMT- $\eta^{\mathbf{1}}-\mathbf{Z}-\mathbf{O}-\mathbf{1}$ and TMT$\eta^{\mathbf{1}} \mathbf{- Z - S - 1}$ complexes as precursors, this activation energy can be estimated at about 115 and $205 \mathrm{~kJ} / \mathrm{mol}$, respectively (see Figure 6). The main difference between both processes is the type of heteroatom initially interacting with the metal. Based on the difference of $\mathrm{C}-\mathrm{N}$ bond length and the charge density at the corresponding $\mathrm{BCP}$ in each complex $\left(\mathrm{d}_{\mathrm{C}-\mathrm{N}}=1.475 \AA\left(\rho_{\mathrm{C}-\mathrm{N}}=0.248\right)\right.$ for TMT- $\boldsymbol{\eta}^{1}-\mathbf{Z}-\mathbf{O}-\mathbf{1}$ and $\mathrm{d}_{\mathrm{C}-\mathrm{N}}=1.495 \AA\left(\rho_{\mathrm{C}-\mathrm{N}}=0.233\right)$ for TMT- $\boldsymbol{\eta}^{\mathbf{1}} \mathbf{- Z}-\mathbf{S}-\mathbf{1}$ ), one may expect that the barrier should be smaller for the latter than for the former. However, the TMT-TS1 and TMT-TS4 transition states associated with these processes not only imply the $\mathrm{C}-\mathrm{N}$ bond cleavage, but also the rupture of the hydrogen bonds involving the donor amino group. Indeed, in TMT- $\boldsymbol{\eta}^{\mathbf{1}} \mathbf{- Z}-\mathbf{S}-\mathbf{1}$, the $\mathrm{NH}_{3}$ group presents two strong hydrogen bonds with the neighboring heteroatoms ( $\mathrm{S}$ and $\mathrm{O}$ ) while in TMT- $\eta^{\mathbf{1}}-\mathbf{Z}-\mathbf{O}-1$ only one hydrogen bond is observed. The strength of these 
HBs can be correlated to the NBO interaction energies between the lone pair of the acceptor and the antibonding $\sigma^{*}{ }_{\mathrm{N}-\mathrm{H}}$ of the donor In fact, while for TMT- $\boldsymbol{\eta}^{\mathbf{1}}-\mathbf{Z}-\mathbf{S}-\mathbf{1}$ complex $\mathrm{E}\left[\mathrm{LP}_{\mathrm{S}}-\sigma_{\mathrm{N}-\mathrm{H}}\right]$ and $\mathrm{E}\left[\mathrm{LP}_{\mathrm{O}}-\sigma^{*}{ }_{\mathrm{N}-\mathrm{H}}\right]$ interaction energies are 38 and $15 \mathrm{~kJ} / \mathrm{mol}$, respectively, for TMT- $\boldsymbol{\eta}^{\mathbf{1}} \mathbf{- Z - O}-\mathbf{1}$ the $\mathrm{E}\left[\mathrm{LP}_{\mathrm{O}}-\sigma^{*}{ }_{\mathrm{N}-\mathrm{H}}\right]$ energy is estimated at $20 \mathrm{~kJ} / \mathrm{mol}$. This might explain the higher activation energy for $\mathrm{NH}_{3}$ elimination in the former. Concerning the product ion generated together with ammonia, it is clear that formation of the $m / z, 253$ ion from TMT- $\boldsymbol{\eta}^{\mathbf{1}} \mathbf{- Z}-\mathbf{S}-\mathbf{1}$ is more favored than from TMT- $\boldsymbol{\eta}^{\mathbf{1}} \mathbf{- Z}-\mathbf{O}-\mathbf{1}$. However, the energy difference is about $37 \mathrm{~kJ} / \mathrm{mol}$ and we may reasonably assume that both processes are possible for the loss of $\mathrm{NH}_{3}$, hence giving support to the high intensity of the corresponding peak onto the MS/MS spectrum. The second loss observed experimentally corresponds to the elimination of $\mathrm{C}_{3} \mathrm{H}_{4} \mathrm{O}_{2} \mathrm{~S}$ in $\left[\left(\mathrm{CH}_{3}\right)_{3} \mathrm{Sn}(\mathrm{Cys})\right]^{+}$complex. As we proposed (vide supra), this elimination suggests the formation of an intermediate that involves an interaction between the metallic center and $\mathrm{NH}_{3}$. As a matter of fact, our calculations show that taking TMT- $\boldsymbol{\eta}^{\mathbf{1}}-\mathbf{N H 2 - 1}$ as precursor, a first $1,3 \mathrm{H}$ transfer from $\alpha$-carbon to nitrogen atom could take place with an associated energy barrier of about $296 \mathrm{~kJ} / \mathrm{mol}$. The resulting intermediate, TMT-min13 (Figure 6), could in turn undergo the scission of an existing $\mathrm{Sn}-\mathrm{O}$ bond and the formation of a new $\mathrm{Sn}-\mathrm{N}$ bond to yield the products. This process requires an activation energy of ca. $399 \mathrm{~kJ} / \mathrm{mol}$. It worth mentioning that following this path the elimination of $\mathrm{NH}_{3}$ can also be reached through the TMT-min4 intermediate. The activation barrier is relatively higher (about $349 \mathrm{~kJ} / \mathrm{mol}$ ) since a 1,2-hydrogen transfer is required before the dissociation of the ammonium species.

\section{Conclusion}


In this work, both experiments and calculations show that di- and tri-organotins exhibit different behavior in the presence of cysteine. Under ESI conditions, TMTCl leads to a single complex, namely $\left[\left(\mathrm{CH}_{3}\right)_{3} \mathrm{Sn}(\mathrm{Cys})\right]^{+}$, whose MS/MS spectra showed elimination of intact cysteine, leading to the formation of $\left[\mathrm{R}_{3} \mathrm{Sn}\right]^{+}$cation. But unlike what was observed with glycine, several additional fragmentation processes occur, namely loss of ammonia and $\mathrm{C}_{3} \mathrm{H}_{4} \mathrm{O}_{2} \mathrm{~S}$. No complexes are observed within bigger groups $(\mathrm{R}=\mathrm{Ph}, \mathrm{n}-\mathrm{Bu})$. Calculations showed that the interaction is mainly electrostatic with some covalent character. Most of the optimized structures are also characterized by the establishment of one or two intramolecular hydrogen bond(s) taking place between the functional groups. Potential energy surfaces associated with the main fragmentation channels have been explored by considering the three most stable forms. Our calculations show that the elimination of ammonia originating from TMT- $\boldsymbol{\eta}^{\mathbf{1}} \mathbf{- Z}-\mathbf{S}-\mathbf{1}$ complex is more favored than the one involving TMT- $\boldsymbol{\eta}^{\mathbf{1}} \mathbf{- Z - O - 1}$. The elimination of $\mathrm{C}_{3} \mathrm{H}_{4} \mathrm{O}_{2} \mathrm{~S}$ suggests TMT- $\boldsymbol{\eta}^{\mathbf{1}} \mathbf{- N H 2 - 1}$ as precursor, involving in a first step a $1,3 \mathrm{H}$ transfer from the $\alpha$-carbon to the nitrogen atom.

Di-organotin formally promote deprotonation of cysteine, leading to $\left[(\mathrm{R})_{2} \operatorname{Sn}(\mathrm{Cys}-\mathrm{H})\right]^{+}$complexes. These complexes share several fragmentation processes, associated with elimination of $\mathrm{NH}_{3}$ and $\left(\mathrm{C}, \mathrm{H}_{2}, \mathrm{O}_{2}\right)$. For these systems, calculations pointed to a preferable bidentate interaction of the type $-\eta^{2}-\mathrm{S}, \mathrm{NH}_{2}$, with sulfur and the amine group. Calculations indicate that the interaction is mostly electrostatic with a significant covalent character. The most energetically-favored fragmentation pathway is the loss of ammonia. Calculations also indicate that interconversion between different structures of the complex is likely to occur prior to dissociation.

\section{Acknowledgments}


Authors would like to thank the LFB (Laboratoire français du Fractionnement et des Biotechnologies, Courtaboeuf, France) for the gift of the QSTAR PULSAR XL instrument. This work has been also supported by the Ministerio de Economía y Competitividad (Project : No. CTQ2012-35513-C02-01), by the STSM COST Action CM1204, and by the Project FOTOCARBON-CM S2013/MIT-2841 of the Comunidad Autónoma de Madrid. Computational time at Centro de Computación Científica (CCC) of Universidad Autónoma de Madrid is also acknowledged. 
[1] D. P. Miller, P. J. Craig, Chemistry of Tin, Springer Netherlands, 1998.

[2] Y. Arakawa, O. Wada, T. H. Yu Toxy. Appl. Pharm. 1981, 60, 1.

[3] M. Hoch Appl. Geochem. 2001, 16, 719.

[4] M. Gielen Coord. Chem. Rev. 1996, 151, 41.

[5] M. Nath, S. Pokharia, R. Yadav Coord. Chem. Rev. 2001, 215, 99.

[6] L. Pellerito, L. Nagy Coord. Chem. Rev. 2002, 224, 111.

[7] G. Arena, R. C., A. Contino, A. Musumeci, S. Musumeci, R. Purrello Inorg. Chimi. Acta. 1995, 237, 187.

[8] M. M. Shoukry Talanta. 1996, 43, 177.

[9] P. Surdy, P. Rubini, N. Buzas, B. Henry, L. Pellerito, T. Gajda Inorg. Chem. 1999, $38,346$.

[10] A. Atkinson, M. D. Rodriguez, T. E. Shewmaker, J. A. Walmsley Inorg. Chim. Acta. 1999, 285, 60.

[11] G. Barone, R. Barbieri, G. La Manna, M. H. J. Koch Appl. Organom. Chem. 2000, $14,189$.

[12] R. Barbieri, A. Silvestri, M. T. Logiudice, G. Ruisi, M. T. Musmeci J. Chem. Soc. Dalton Trans. 1989, 519.

[13] M. T. Musmeci, G. Madonia, M. T. Logiudice, A. Silvestri, G. Ruisi, R. Barbieri Appl. Organom. Chem. 1992, 6, 127.

[14] G. Domazetis, R. J. Magee, B. D. James J. Organom. Chem. 1978, 162, 239.

[15] A. Silvestri, D. Duca, F. Huber Appl. Organom. Chem. 1988, 2, 417.

[16] N. Buzás, T. Gajda, E. Kuzmann, L. Nagy, A. Vertes, K. Burger Main Group Metal Chemistry. 1995, 18, 641.

[17] M. J. Hynes, M. Odowd J. Chem. Soc. Dalton Trans. 1987, 563.

[18] G. Berthon Pure Appl. Chem. 1995, 67, 1117.

[19] R. Spezia, G. Tournois, T. Cartailler, J. Tortajada, Y. Jeanvoine J. Phys. Chem. A. 2006, $110,9727$.

[20] E. Bottari, M. R. Festa Talanta. 1997, 44, 1705.

[21] S. S. Khaloo, M. K. Amini, S. Tangestaninejad, S. Shahrokhian, R. Kia J. Iran. Chem. Soc. 2004, 1, 128.

[22] C. Mathe, T. A. Mattioli, O. Horner, M. Lombard, J. M. Latour, M. Fontecave, V. Niviere J. Am. Chem. Soc. 2002, 124, 4966.

[23] I. Endo, M. Nojiri, M. Tsujimura, M. Nakasako, S. Nagashima, M. Yohda, M. Odaka J. Inorg. Biochem. 2001, 83, 247.

[24] A. Miyanaga, S. Fushinobu, K. Ito, T. Wakagi Biochem. Biophys. Res. Comm. 2001, 288, 1169.

[25] O. V. Nemirovskiy, M. L. Gross J. Am. Soc. Mass Spectr. 1997, 8, 199.

[26] O. V. Nemirovskiy, M. L. Gross J. Am. Soc. Mass Spectr. 1998, 9, 1285.

[27] W. Buchmann, R. Spezia, G. Tournois, T. Cartailler, J. Tortajada J. Mass Spectr. 2007, 42, 517.

[28] P. B. Armentrout, E. I. Armentrout, A. A. Clark, T. E. Cooper, E. M. S. Stennett, D. R. Carl J. Phys. Chem. B. 2010, 114, 3927.

[29] R. Shankar, P. Kolandaivel, L. Senthilkumar J. Phys. Org. Chem. 2011, 24, 553.

[30] P. B. Armentrout, Y. Chen, M. T. Rodgers J. Phys. Chem. A. 2012, 116, 3989.

[31] P. B. Armentrout, S. J. Ye, A. Gabriel, R. M. Moision J. Phys. Chem. B. 2010, 114, 3938. 
[32] M. Hurtado, O. Mó, M. Yáñez, B. Herrera, A. M. Lamsabhi Comput. Theor. Chem. 2014, 1047, 38.

[33] M. Hurtado, M. Monte, A. M. Lamsabhi, M. Yáñez, O. Mó, J. Y. Salpin Chempluschem. 2013, 78, 1124.

[34] I. V. Chernushevich, A. V. Loboda, B. A. Thomson J. Mass Spectr. 2001, 36, 849.

[35] C. Trujillo, O. Mó, M. Yáñez, J. Tortajada, J.-Y. Salpin J. Phys. Chem. B. 2008, $112,5479$.

[36] A. Eizaguirre, O. Mó, M. Yáñez, J.-Y. Salpin Phys. Chem. Chem. Phys. 2011, 13, 17409.

[37] R. Peverati, D. G. Truhlar J. Phys. Chem. Lett. 2012, 3, 117.

[38] M. J. Frisch, G. W. Trucks, H. B. Schlegel, G. E. Scuseria, M. A. Robb, J. R. Cheeseman, G. Scalmani, V. Barone, B. Mennucci, G. A. Petersson, H. Nakatsuji, M. Caricato, X. Li, H. P. Hratchian, A. F. Izmaylov, J. Bloino, G. Zheng, J. L. Sonnenberg, M. Hada, M. Ehara, K. Toyota, R. Fukuda, J. Hasegawa, M. Ishida, T. Nakajima, Y. Honda, O. Kitao, H. Nakai, T. Vreven, J. A. Montgomery Jr., J. E. Peralta, F. Ogliaro, M. Bearpark, J. J. Heyd, E. Brothers, K. N. Kudin, V. N. Staroverov, R. Kobayashi, J. Normand, K. Raghavachari, A. Rendell, J. C. Burant, S. S. Iyengar, J. Tomasi, M. Cossi, N. Rega, J. M. Millam, M. Klene, J. E. Knox, J. B. Cross, V. Bakken, C. Adamo, J. Jaramillo, R. Gomperts, R. E. Stratmann, O. Yazyev, A. J. Austin, R. Cammi, C. Pomelli, J. W. Ochterski, R. L. Martin, K. Morokuma, V. G. Zakrzewski, G. A. Voth, P. Salvador, J. J. Dannenberg, S. Dapprich, A. D. Daniels, O. Farkas, J. B. Foresman, J. V. Ortiz, J. Cioslowski, D. J. Fox in Gaussian09, version: Revision C.01, 2009,

[39] R. Li, R. Peverati, M. Isegawa, D. G. Truhlar J. Phys. Chem. A. 2013, 117, 169.

[40] N. Mardirossian, M. Head-Gordon J. Chem.Theory Comput. 2013, 9, 4453.

[41] H. Liu, J. E. Bara, C. H. Turner J. Phys. Chem. A. 2014, 118, 3944.

[42] S. Liu, H. Shen, Z. Yu, L. Shi, Z. Yang, Y. Lan Organometal. 2014, 33, 6282.

[43] T. Schwabe Phys. Chem. Chem. Phys. 2014, 16, 14559.

[44] B. Metz, H. Stoll, M. Dolg J. Chem. Phys. 2000, 113, 2563.

[45] P. Matczak Comput. Theor. Chem. 2015, 1051, 110.

[46] T. Ziegler, A. Rauk Theor Chim Acta. 1977, 46, 1.

[47] F. M. Bickelhaupt, E. J. Baerends in Kohn-Sham Density Functional Theory: Predicting and Understanding Chemistry, Vol. (Eds.: K. B. Lipkowitz, D. B. Boyd), John Wiley \& Sons, Inc., 2007, pp.1.

[48] K. Kitaura, K. Morokuma Int. J. Quantum Chem. 1976, 10, 325.

[49] V. U. A. Theoretical Chemistry in Amsterdam Density Functional (ADF) program, http://www.scm.com., version, 2016,

[50] R. F. W. Bader, Atoms In Molecules : A Quantum Theory, Clarendon Press Oxford Univ., Oxford, 1990.

[51] C. F. Matta, R. J. Boyd, The Quantum Theory of Atoms in Molecules, Wiley-VCH Verlag GmbH \& Co., KGaA: Wein- heim, 2007.

[52] T. A. Keith in AIMAll, aim.tkgristmill.com, version: 15.05.18, 2015,

[53] F. Weinhold, C. R. Landis, Valency and Bonding: A Natural Bond Orbital DonorAcceptor Perspective, Cambridge University Press, Cambridge, 2005.

[54] P. Cardiano, C. De Stefano, O. Giuffre, S. Sammartano Biophys. Chem. 2008, 133, 19.

[55] L. Latrous, J. Tortajada, V. Haldys, E. Leon, C. Correia, J. Y. Salpin J. Mass Spectr. 2013, 48, 795.

[56] C. Muetterties, A. Janiga, K. T. Huynh, M. G. Pisano, V. T. Tripp, D. D. Young, J.

C. Poutsma Inter. J. Mass Spectr. 2014, 369, 71. 
[57] J.-Y. Salpin, S. Guillaumont, J. Tortajada, L. MacAleese, J. Lemaire, P. Maitre ChemPhysChem. 2007, 8, 2235.

[58] J. M. Bakker, R. K. Sinha, T. Besson, M. Brugnara, P. Tosi, J.-Y. Salpin, P. Maître J. Phys. Chem. A. 2008, 112, 12393.

[59] E. R. Molina, D. Ortiz, J.-Y. Salpin, R. Spezia J. Mass Spectr. 2015, 50, 1340.

[60] E. Rossich Molina, J.-Y. Salpin, R. Spezia, E. Martinez-Nuñez Phys. Chem. Chem. Phys. 2016, 18, 14980.

[61] F. Rogalewicz, Y. Hoppilliard Int. J. Mass Spect. 2000, 199, 225.

[62] Y. Hoppilliard, G. Ohanessian, S. Bourcier J. Phys. Chem. A. 2004, 108, 9687. 


\section{Figure captions}

Figure 1: ESI mass spectra of the cysteine/DPhTCl mixture $\left([\mathrm{Cys}]=5 \times 10^{-4} \mathrm{M}\right.$, $\left.[\mathrm{DPhTCl}]=10^{-4} \mathrm{M}\right)$ in methanol/water $(50 / 50 \mathrm{v} / \mathrm{v})$ recorded with a DP of $50 \mathrm{~V}$.

Figure 2: MS/MS spectrum of a) $\left[\left(\mathrm{CH}_{3}\right)_{3} \mathrm{SnCys}\right]^{+}$and b) $\left[\left(\mathrm{CH}_{3}\right)_{2} \mathrm{Sn}(\mathrm{Cys}-\mathrm{H})\right]^{+}$ions recorded with a collision energy of $14 \mathrm{eV}$ (laboratory frame).

Figure 3: Relative energies of $\left[\left(\mathrm{CH}_{3}\right)_{2} \mathrm{Sn}(\mathrm{Cys}-\mathrm{H})\right]^{+}$complexes (in $\mathrm{kJ} / \mathrm{mol}$ ) at the $\operatorname{CCSD}(\mathrm{T}) / 6-31+\mathrm{G}^{* *} / / \mathrm{M} 11 \mathrm{~L} / 6-31+\mathrm{G}^{* *}$ level of theory. In parenthesis the relative energies from the optimization at the M11L/6-31+G** level.

Figure 4: Relative energies of $\left[\left(\mathrm{CH}_{3}\right)_{3} \mathrm{SnCys}\right]^{+}$complexes (in $\mathrm{kJ} / \mathrm{mol}$ ) at the $\operatorname{CCSD}(\mathrm{T}) / 6-31+\mathrm{G}^{* *} / / \mathrm{M} 11 \mathrm{~L} / 6-31+\mathrm{G}^{* *}$ level of theory. In parenthesis the relative energies from the optimization at the M11L/6-31+G** level.

Figure 5: Energy profile associated with the formation of $\mathrm{NH}_{3}$ and $\mathrm{HOCOH}$ fragments from $\left[\left(\mathrm{CH}_{3}\right)_{2} \mathrm{Sn}(\mathrm{Cys}-\mathrm{H})\right]^{+}$. Relative energies are in $\mathrm{kJ} / \mathrm{mol}$ at the $\mathrm{CCSD}(\mathrm{T}) / 6$ $31+\mathrm{G}^{* *} / / \mathrm{M} 11 \mathrm{~L} / 6-31+\mathrm{G}^{* *}$ level of theory. In parenthesis the relative energies at the M11L/6-31+G** level.

Figure 6: Energy profile associated with the formation of $\mathrm{NH}_{3}$ and $\left(\right.$ Cysteine- $\left.\mathrm{NH}_{3}\right)$ fragments from the $\left[\left(\mathrm{CH}_{3}\right)_{3} \mathrm{SnCys}\right]^{+}$complex. Energies are in $\mathrm{kJ} / \mathrm{mol}$ at the $\mathrm{CCSD}(\mathrm{T}) / 6$ $31+\mathrm{G}^{* *} / / \mathrm{M} 11 \mathrm{~L} / 6-31+\mathrm{G}^{* *}$ level of theory. In parenthesis the energies at M11L/6$31+\mathrm{G}^{* *}$

Scheme 1: global dissociation scheme for the $\left[\left(\mathrm{CH}_{3}\right)_{3} \mathrm{SnCys}\right]^{+}$complex.

Scheme 2: global dissociation scheme for the $\left[(\mathrm{R})_{2} \mathrm{Sn}(\mathrm{Cys}-\mathrm{H})\right]^{+}$complexes. 


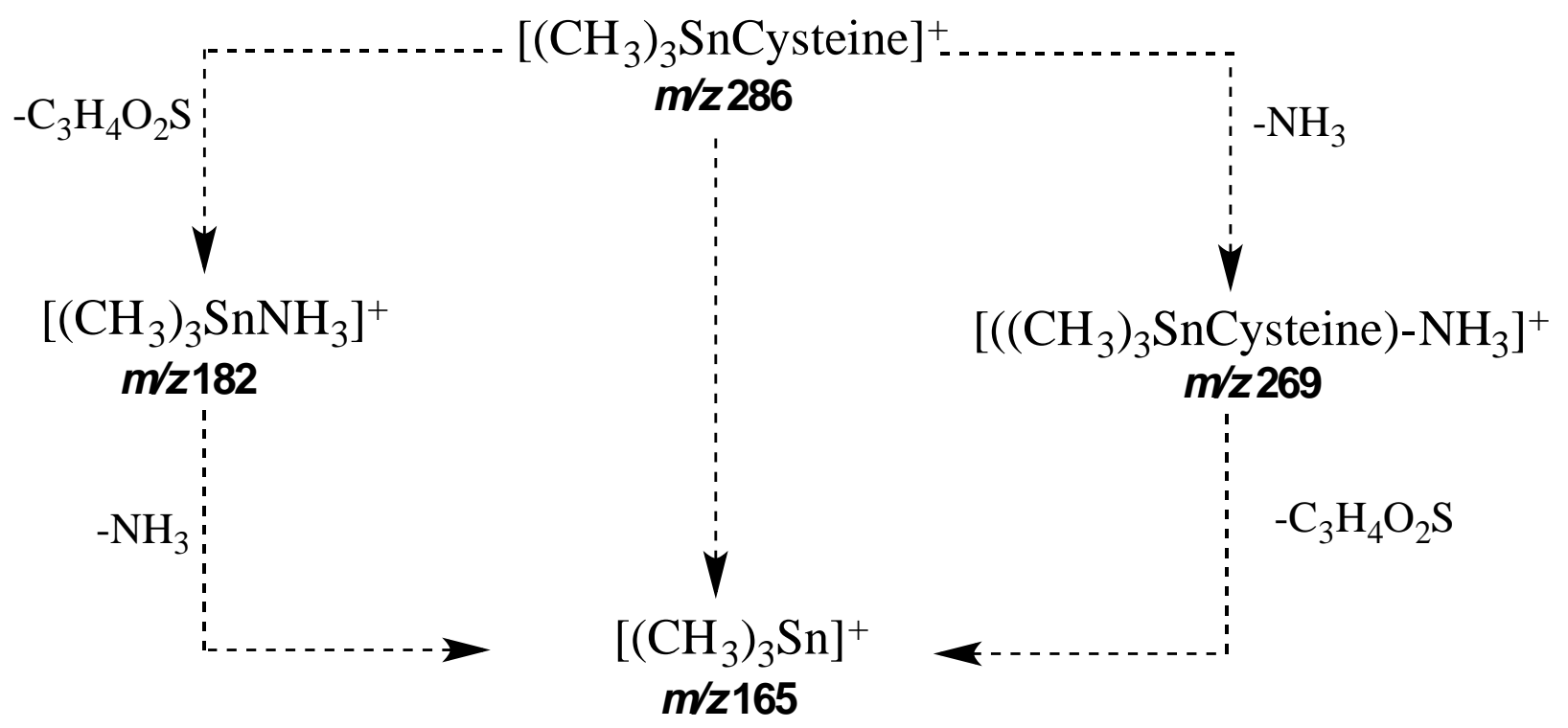

Scheme 1. 


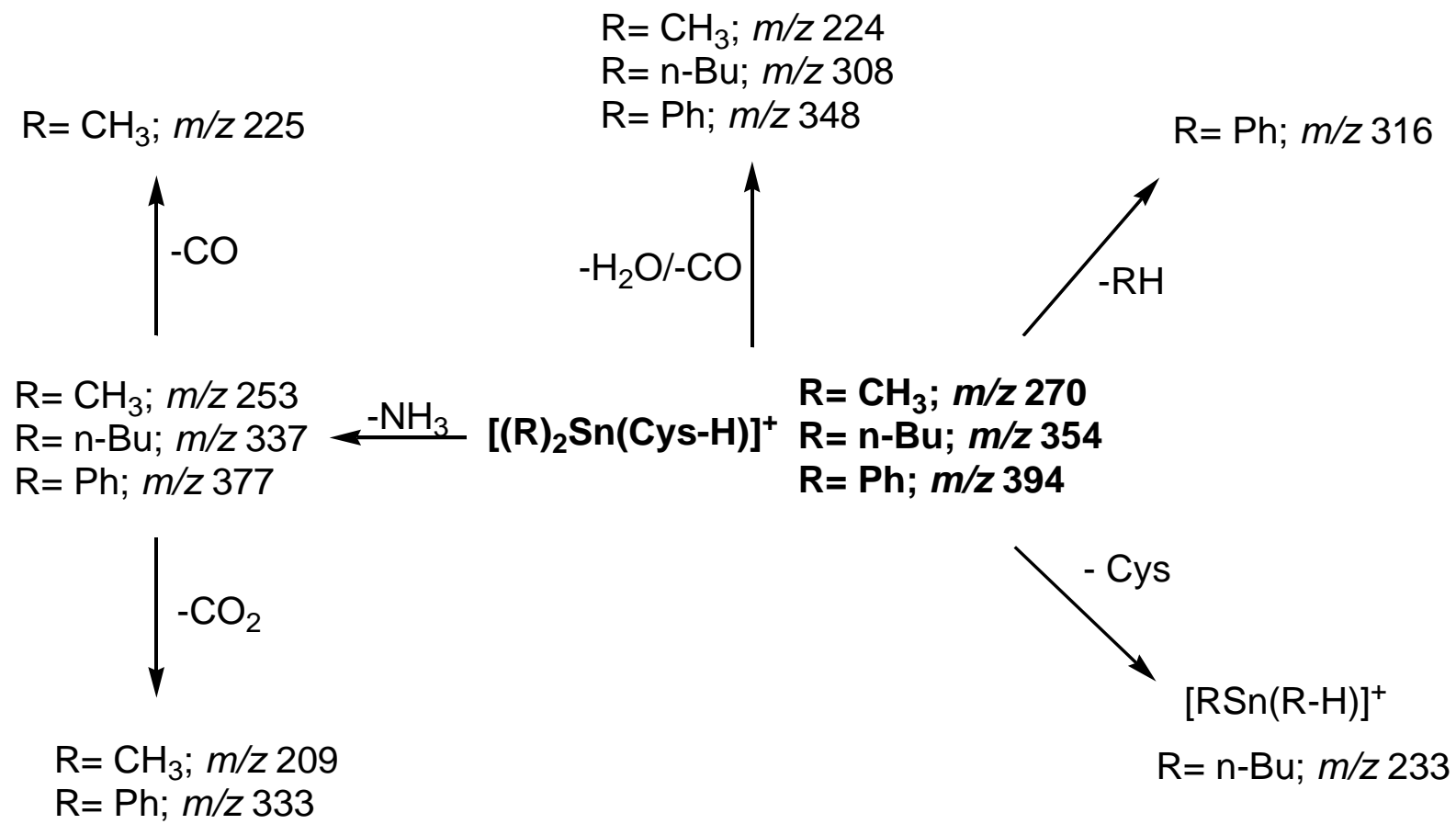

Scheme 2. 


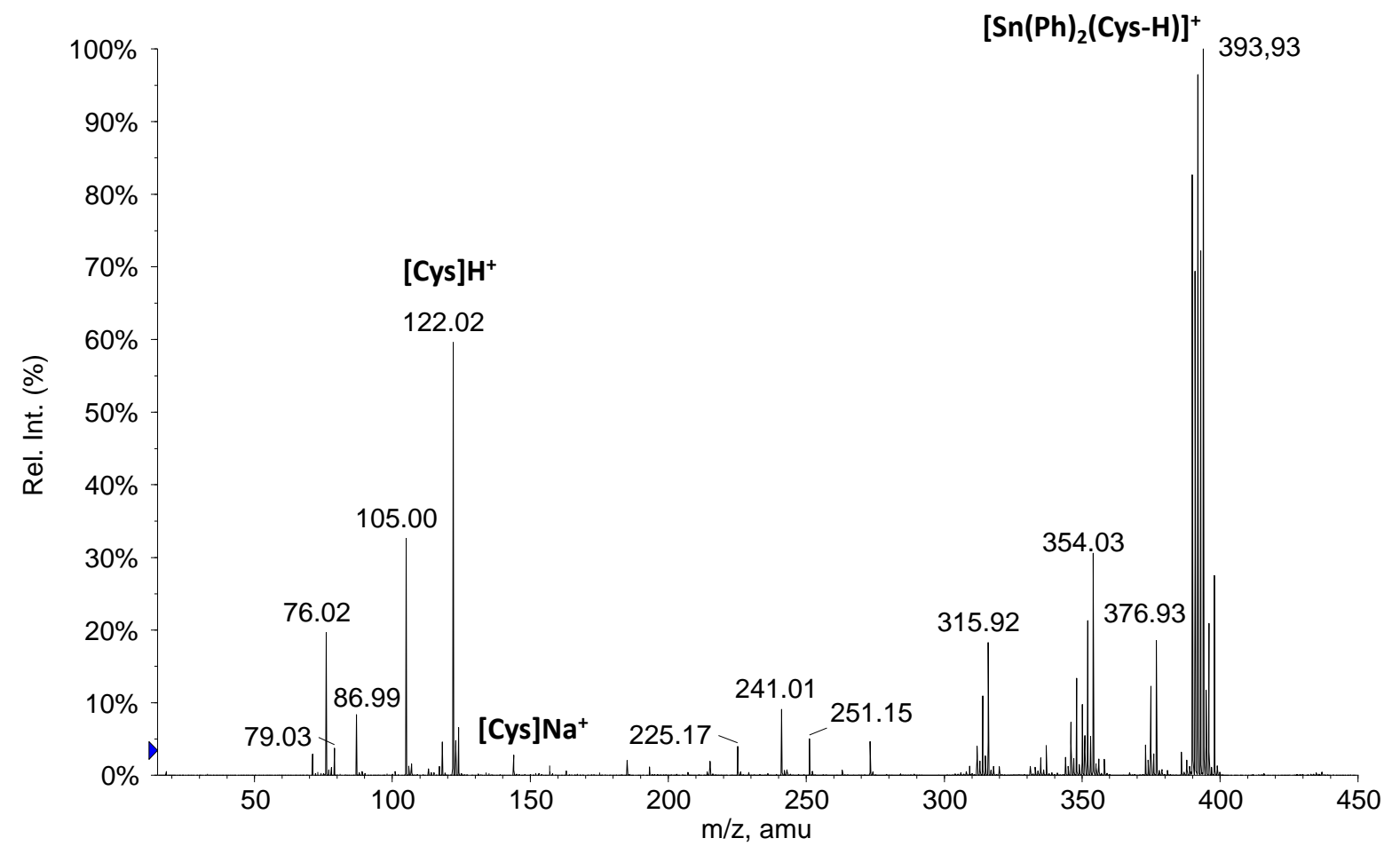

Figure 1. 

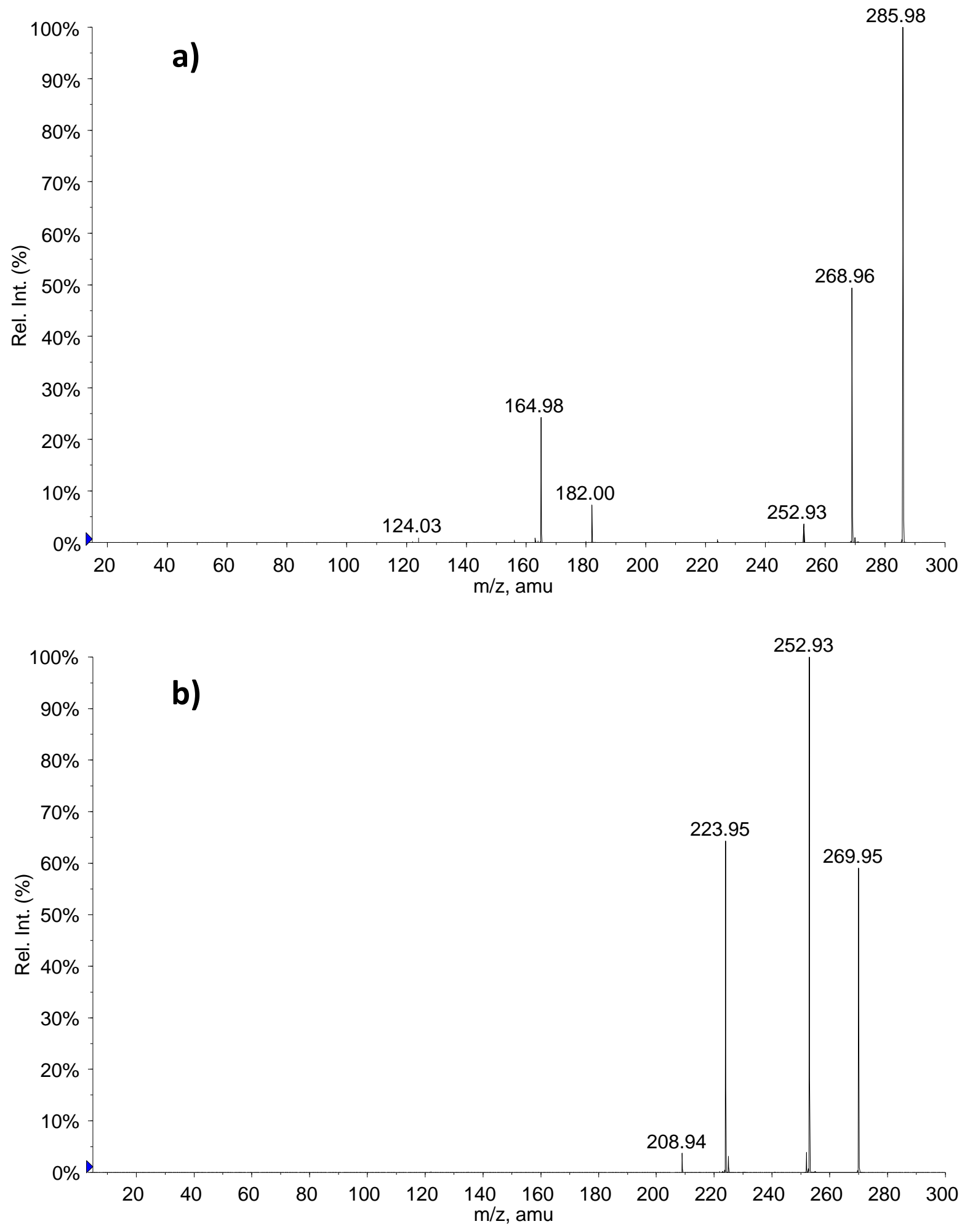

Figure 2. 


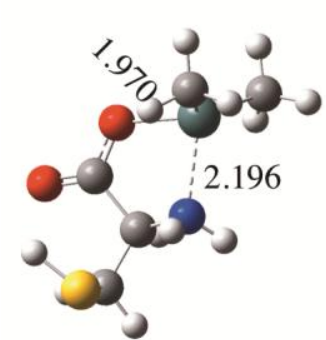

DMT- $\eta^{2}-\mathrm{O}, \mathrm{NH} 2-1$ 66 (62)

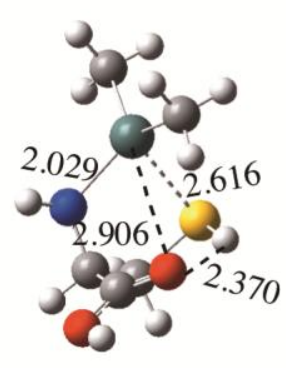

DMT- $\eta^{2}-\mathrm{SH}, \mathrm{NH}$ 102(95)

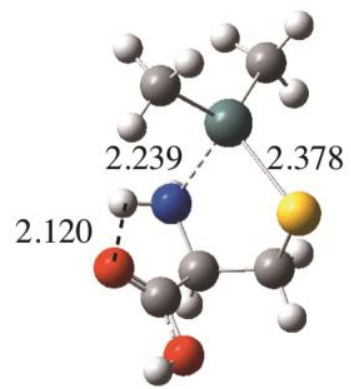

DMT- $\eta^{2}-\mathrm{S}-\mathrm{NH} 2$

$0(0)$

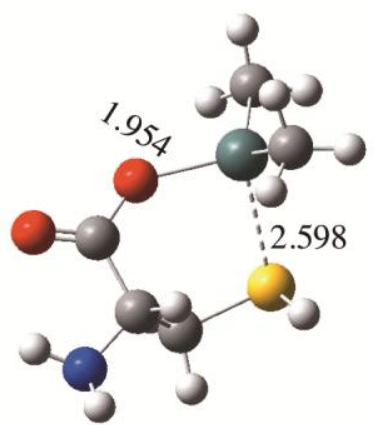

DMT- $\eta^{2}-\mathrm{O}, \mathrm{SH}-1$ 133(123)

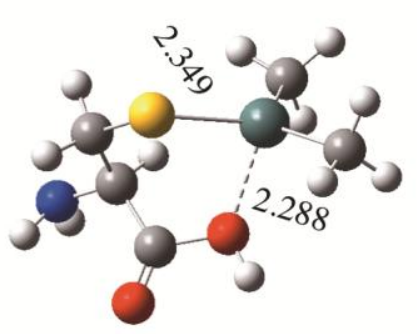

DMT- $\eta^{2}-\mathrm{OH}, \mathrm{S}$ 109(108)

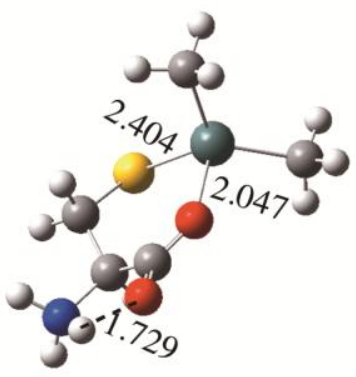

DMT- $\eta^{2}-Z-O, S-2$ $31(27)$

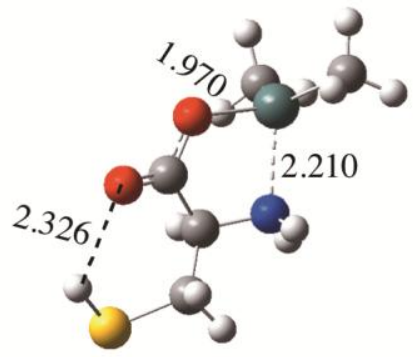

DMT- $\eta^{2}-\mathrm{O}, \mathrm{NH} 2-2$

92 (91)

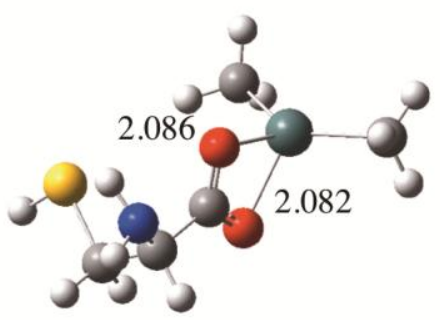

DMT- $\eta^{2}-\mathrm{O}, \mathrm{O}-1$ 103(89)

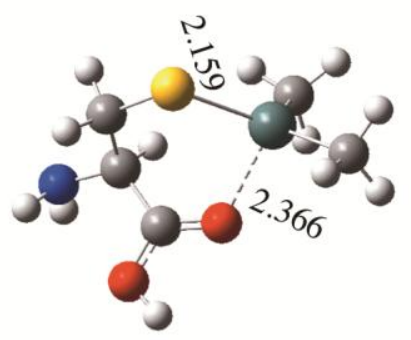

DMT- $\eta^{2}-\mathrm{O}, \mathrm{S}-1$ 65(51)

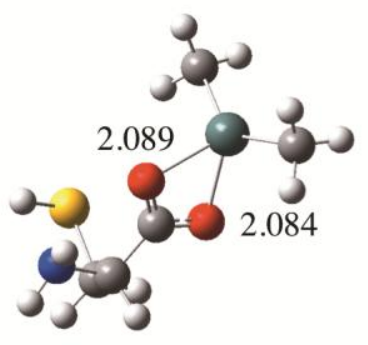

DMT- $\eta^{2}-\mathrm{O}, \mathrm{O}-2$ 96(78)

Figure 3. 

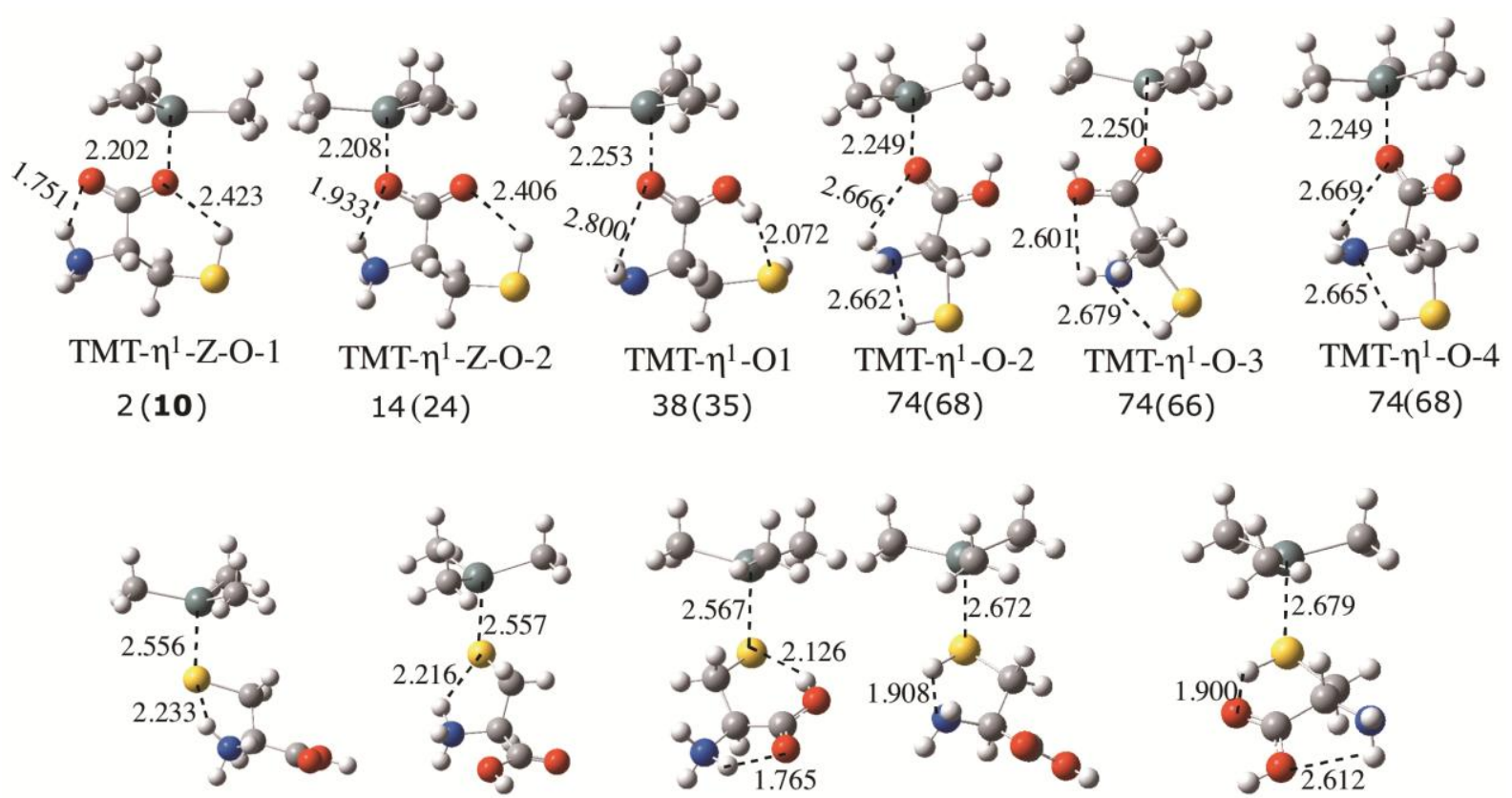

TMT- $\eta^{1}-\mathrm{Z}-\mathrm{S}-1 \quad$ TMT- $\eta^{1}-\mathrm{Z}-\mathrm{S}-2$

TMT- $\eta^{1}-\mathrm{Z}-\mathrm{S}-3 \quad$ TMT- $\eta^{1}-\mathrm{S}-1$

18(18)

33(36)

57(55)

49(50)

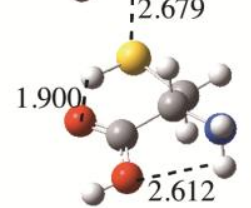

TMT- $\eta^{1}-\mathrm{S}-2$

$63(65)$

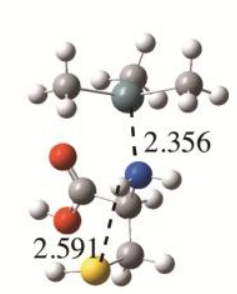

TMT- $\eta^{1}-\mathrm{NH} 2-1$ $\mathbf{0}(0)$

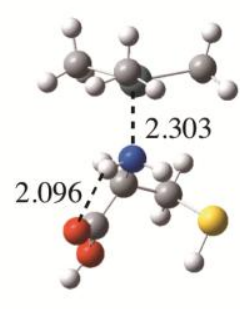

TMT- $\eta^{1}-\mathrm{NH} 2-2$ $6(10)$

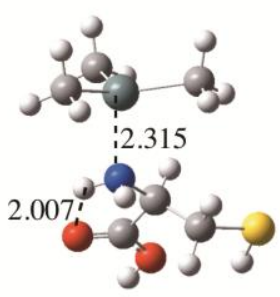

TMT- $\eta^{1}-\mathrm{NH} 2-3$ 28(32)

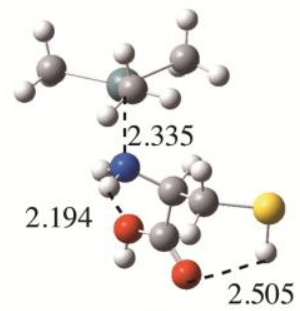

TMT- $\eta^{1}-\mathrm{NH} 2-4$ 34(42)

Figure 4. 


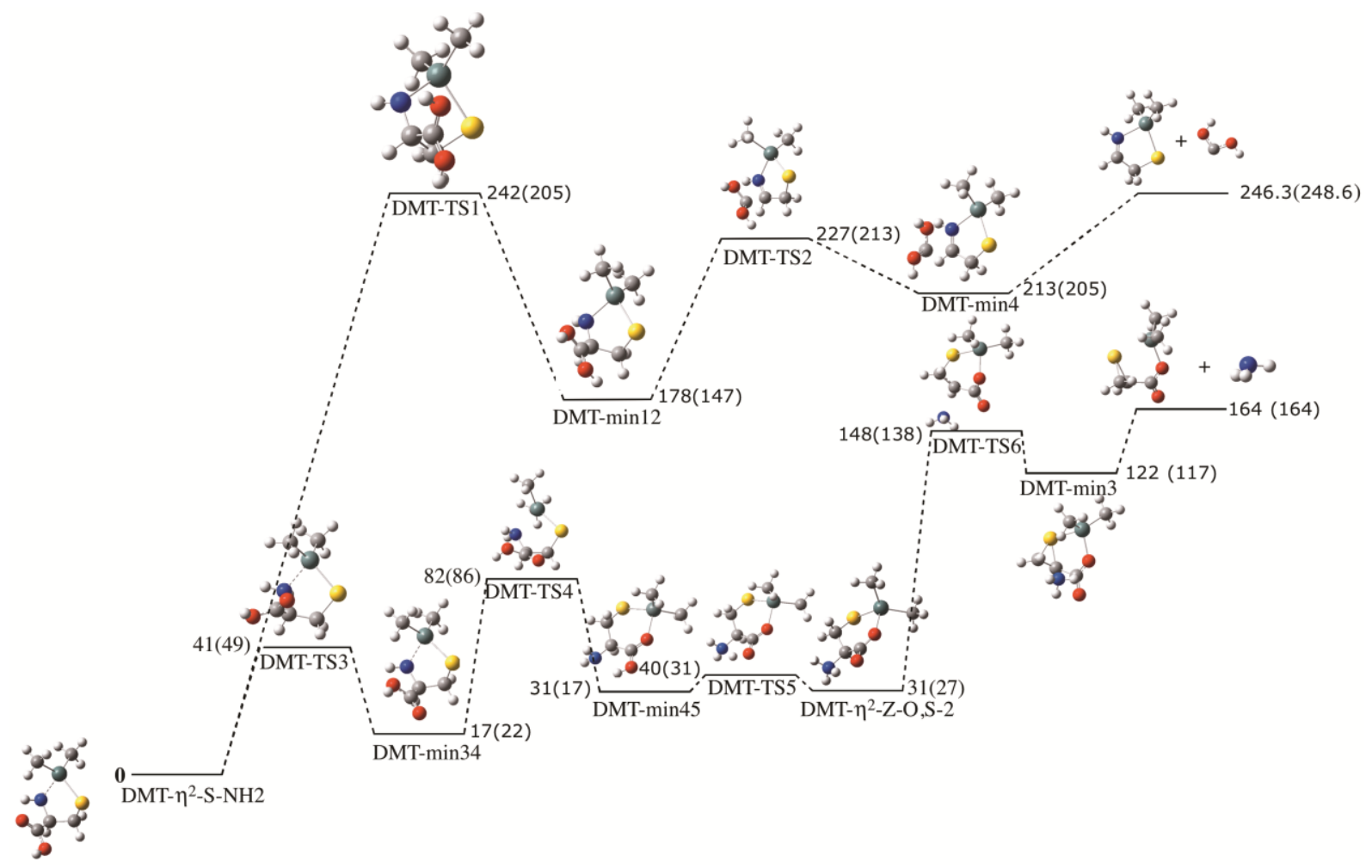

Figure 5. 


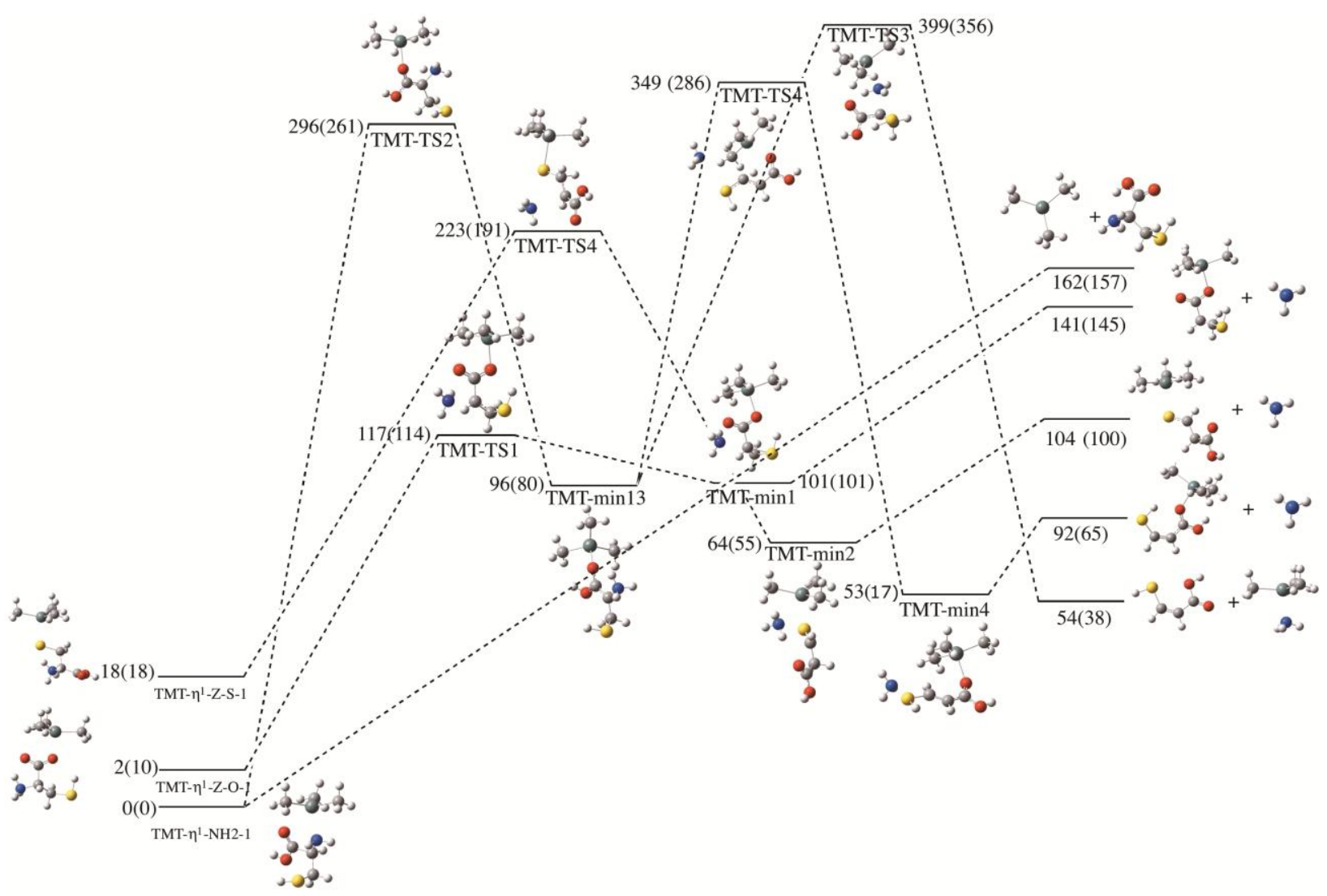

Figure 6. 
Table 1: Natural charge (in $e$ ) on the metal and DMT moiety in the complex and Wiberg index of the most relevant bonds in the complexes.

\begin{tabular}{|l|c|r|r|r|r|r|}
\hline & \multicolumn{3}{|c|}{ Charge $(e)$} & \multicolumn{3}{c|}{ Wiberg bond Index } \\
\hline & $\mathrm{Q}_{\mathrm{Sn}}$ & $\mathrm{Q}_{\mathrm{Sn}(\mathrm{CH} 3) 2}$ & $\mathrm{Q}_{\text {(cyst-H) }}$ & \multicolumn{1}{c|}{ Sn-S } & \multicolumn{1}{c|}{ Sn-N } & \multicolumn{1}{c|}{ Sn-O } \\
\hline DMT- $\eta^{2}-\mathrm{S}, \mathrm{NH} 2$ & 1.944 & 1.128 & -0.128 & 0.834 & 0.308 & - \\
\hline DMT- $\eta^{2}-\mathrm{O}, \mathrm{S}-2$ & 2.038 & 1.228 & -0.228 & 0.760 & - & 0.314 \\
\hline DMT- $\eta^{2}-\mathrm{O}, \mathrm{O}-2$ & 2.255 & 1.550 & -0.550 & & - & 0.317 \\
\hline DMT- $\eta^{2}-\mathrm{SH}, \mathrm{NH}$ & 2.084 & 1.270 & -0.270 & 0.461 & 0.557 & - \\
\hline
\end{tabular}


Table 2: Natural charge (in $e$ ) on the metal and DMT moiety in the complex and Wiberg index of the most relevant bonds in the complexes.

\begin{tabular}{|c|c|c|c|c|c|c|}
\hline & \multicolumn{3}{|c|}{ Charge $(e)$} & \multicolumn{3}{|c|}{ Wiberg bond Index } \\
\hline & $\mathrm{Q}_{\mathrm{Sn}}$ & $\mathrm{Q}_{\mathrm{Sn}(\mathrm{CH} 3) 3}$ & $\mathrm{Q}_{\text {Cysteine }}$ & Sn-S & Sn-N & Sn-O \\
\hline TMT- $\eta^{1}-\mathrm{NH} 2-1$ & 2.150 & 0.795 & 0.205 & - & 0.265 & - \\
\hline TMT- $\eta^{1}-\mathrm{Z}-\mathrm{O}-1$ & 2.138 & 0.808 & 0.192 & - & - & 0.282 \\
\hline TMT- $\eta^{1}-Z-S-1$ & 1.936 & 0.616 & 0.384 & 0.595 & - & - \\
\hline TMT- $\eta^{1}-S-1$ & 1.955 & 0.688 & 0.312 & 0.462 & - & - \\
\hline
\end{tabular}

